\title{
An Analysis of Socio-Economic Growth of Coastal Society in Belitung Regency, Bangka Belitung Islands Province, Indonesia
}

\author{
Yudi Antomi ${ }^{1)}$ and Paus Iskarni ${ }^{1)}$ \\ 1) Lecturers of Master Program of Geography Education \\ Faculty of Social Science, Universitas Negeri Padang, Indonesia \\ Email: tmy_bima@yahoo.com
}

\begin{abstract}
The purpose of this research was to analyze socio-economic growth rate of coastal society in Belitung Regency, Bangka Belitung Islands Province, Indonesia. The research was conducted through a secondary analysis, followed by focus group discussion (FGD), and processed using analytical techniques hierarchical process (AHP) with relevant government informants and community (stakeholders). Based on the results, the policy priorities are taken into consideration in the decision-making with respect to the vulnerability socioeconomic of coastal society in Belitung Regency. The five alternatives policy priorities are: (1) involving the coastal society in the tourism sector, (2) making ecotourism based trade center, (3) optimizing the use of the land seashores into economy sectors, (4) establishing informal institutions related to coastal society, and (5) establishing the formal institutions related to coastal area.
\end{abstract}

Keywords: Vulnerability, Social Economy, Coastal Society

\section{Introduction}

The coastal area is a transition area between the land and ocean ecosystems which depend on each other. If there is damage done to one of the ecosystem courses, it will affect the stability of ecosystems. According to Law No. 24 2007, vulnerability is a condition or characteristic geological, biological, hydrological, climatological, geographical, social, cultural, political, economic, and technology in an area for a certain period of time which reduces the ability to prevent, mitigate, reach, readiness, and reduce the ability to respond to the adverse impact of certain hazards. In addition, based on the International Strategy For Disaster Reduction (ISDR) stated in Diposaptono (2007), the vulnerability is a condition determined by physical, social, economic and environmental factors. Based on characteristics stated, the coastal region can be grouped into: a. The physical characteristics of the coast, and b. Social and economic characteristics of the coast. Socioeconomic according Abdulsyani in Maftukhah (2007) is the status or position of someone in the group of people which is determined by the type of economic activity, income, educational level, age, residence, and property owned. Belitung Regency is also known as the producer of the largest tin mining in Indonesia after the Bangka Island. In addition, the potential of marine fishery resources in Belitung with the production of 5.858 tons per year, consistently contribute to the economy of Belitung (Belitung In Figures 2015).

A total of 15686 households of fishermen depend their livelihood from the sea. Besides rich in pelagic fish species such as mackerel, snapper and yellow tail, this region also has the kind of demersal fish such as stingrays. The existence of these fish and the sea which locations are open for directly connected with the South China Sea which led the foreign fishermen to fish in the sea of Bangka Belitung Islands Province. The local government is already aware not to be too dependent on the mining sector, given the nature of the mining sector as a irrenewable resource. By only focusing on the mining sector, it can make the economy of Bangka Belitung Islands Province become vulnerable to shocks. According to the data obtained, the number 
of workers in Bangka Belitung Islands Province is higher than the number of jobs available. It is caused by a number of inherent problems caused by mining that have prevented the people's welfare. It is undeniable that IT activities in Bangka Belitung Islands Province have spurred rapid economic growth. However, not only the economic growth generated by the IT, it also cause devastating environmental damage due to the sporadic and bulk mining activities. Most miners use heavy equipments that easily rip the ground. The waste of mining activities which flow into the river also causes the silting of the river. Based on the problems described, the researchers were interested in doing research on the analysis of the socio-economic growth of coastal society in Belitung Regency, Bangka Belitung Islands Province, Indonesia, with focus of problems: 1) the level of socio-economic growth of coastal society in Belitung Regency, and 2) the alternative policies on socio-economic in the coastal area of Belitung Regency.

\section{Method}

The analysis of the growth rate of the social economy of coastal society was done in a qualitative descriptive research, carried out through a secondary analysis, followed by focus group discussion (FGD). The informants were the government institutions Belitung (BAPEEDA), the experts (universities) and the coastal society. The priority policies were analyzed by using analytical hierarchical process (AHP). The research was done in Belitung Regency including the Subdistricts of Tanjung Pandan, Membalong, and Badau from July $26^{\text {th }}$ to August $1^{\text {st }}, 2016$. The data used were primary data and secondary data. The primary data were obtained through observations and interviews, and the secondary data as the data supporters were obtained from BAPEEDA and CBS.

\section{Results and Discussion}

The coastal area is the sea area that is associated with the cultivation, and the land areas behind the coastal border line that are directly related to the socio-economic activities in the border region of coastal and marine waters. Based on Law No. 27 of 2007 concerning the Management of Coastal Areas and Small Islands, the coastal areas are calculated to the area of land that is from the shoreline to the administrative boundaries, and 12 miles seaward calculated from the shoreline. Therefore, the coastal area is an area or region which is rich in potential in terms of economy, tourism, resources and great disaster. However, in the limits of ecology, coastal areas to inland are still influenced by the sea and the sea is still affected by the land (Dahuri 2008:5-6). Geographically, Belitung Regency is located between 107 008' ET to 107058 ' ET and 02 030' SL to 03 015' SL with the area of 229.369 ha. Belitung Regency is a part of Bangka Belitung Islands Province region. This regency consists of about a hundred of big and small islands. In the world map, it is known as Billiton with East-West diameter $+79 \mathrm{~km}$ and the center line of the North-South $+77 \mathrm{~km}$. According to its location, quartz stones and sand are spread evenly throughout the area that reach 266.865 ha or 56.98 percent of the Belitung Regency. Alluvial stones can also be found in almost every part of the regency that reach133.5 km2 in total, except the Subdistrict Selat Nasik.

Belitung Regency is a part of Bangka Belitung Islands Province region. This regency consists of about a hundred of big and small islands. The largest island in Belitung Regency is Belitung island. In addition, there are other large islands, such as Seliu Island, Mendanau Island, and Nadu Island. The population of Belitung Regency based on the result of the population project in 2015 amounted to 175.048 inhabitants with a growth rate of 2.20 percent from 2014 to 2015. The numbers of males in 2015 were 90.600 inhabitants and the populations of women were 84.448 inhabitants. The greatest economical contributions of Belitung Regency in 2014 came from the tertiary sector with a contribution of 35.69 percent. The tertiary sector consists of the hotel and restaurant sector, transport and communications sector, real estate and corporate services sector, and the services sector. Their respective contributions were 13.52 percent; 4.63 percent; 3.55 percent; and 16.49 percent. 
Based on the results of interviews conducted, there are still some obstacles faced by the of coastal society which are there is no informal institutions to embrace the aspirations of the coastal society, and some people have not been able to utilize their lands as the economical source of coastal region due to the government related problems. Therefore, some alternative policies are offered to help the coastal society to solve their problems. There are three criteria for designing the policy in the policy hierarchy which are the social status, economic status, and institutional. Based on these criteria, ten alternative policies were then obtained (Figure 1)

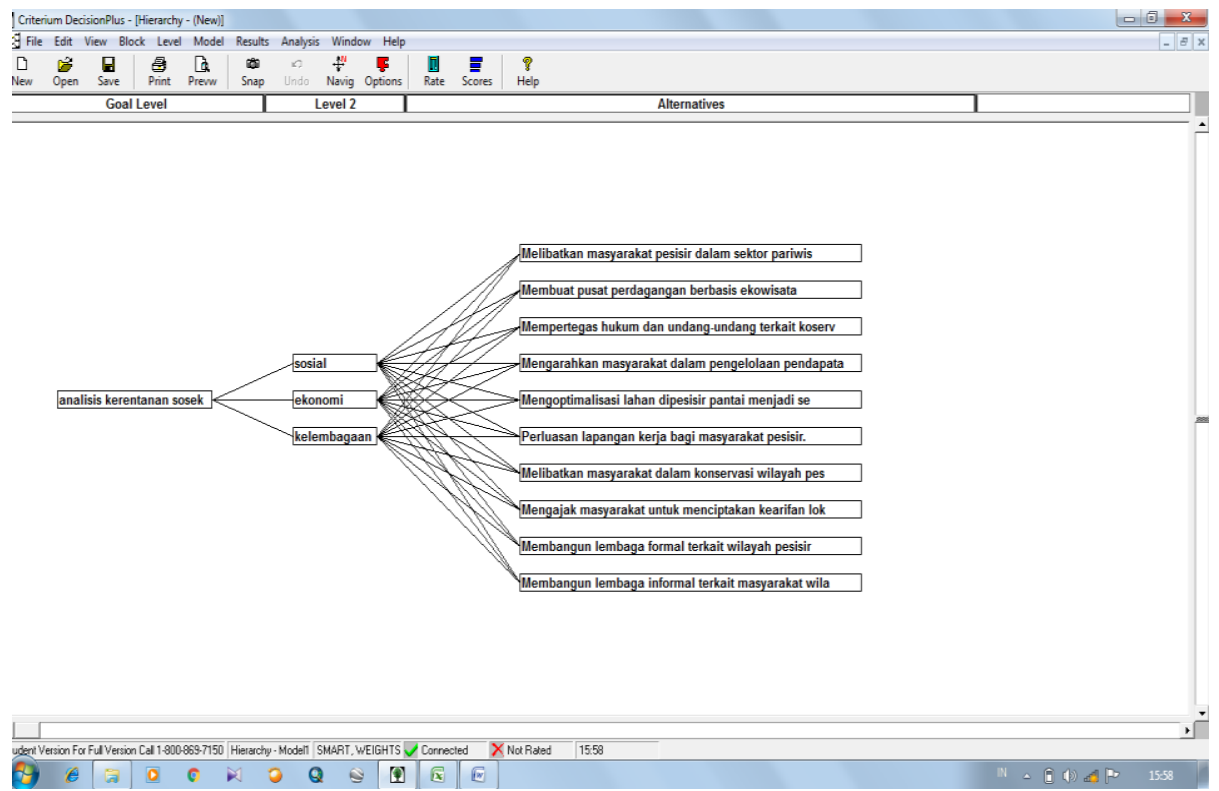

Figure 1. Hierarchy of Alternative Policies in the Development of the Socio-Economic Growth of Coastal Society in Belitung Regency

Of the ten alternative policies, five policy priorities were fromulated based on the calculation of the ratio consistency with the requirements of data should be consistent or $<0.1$. Figure 2 shows the values obtained with consistency ratio 0.063 . Therefore, the policy hierarchy compiled in this research is consistent and can be used. The consistency of the policy was 0.016 or $<0.1$, so it could proceed with setting policy priorities. Based on the results of focus group discussion conducted with the local government of Belitung Regency, the Department of Social, the Department of Tourism, the universities, the Department of Spatial Planning, and the community leaders, the five policy priorities are decided: (1) involving the coastal society in the tourism sector, (2) making ecotourism based trade center, (3) optimizing the use of the land seashores into economy sectors, (4) establishing informal institutions related to coastal society, and (5) establishing the formal institutions related to coastal area. 


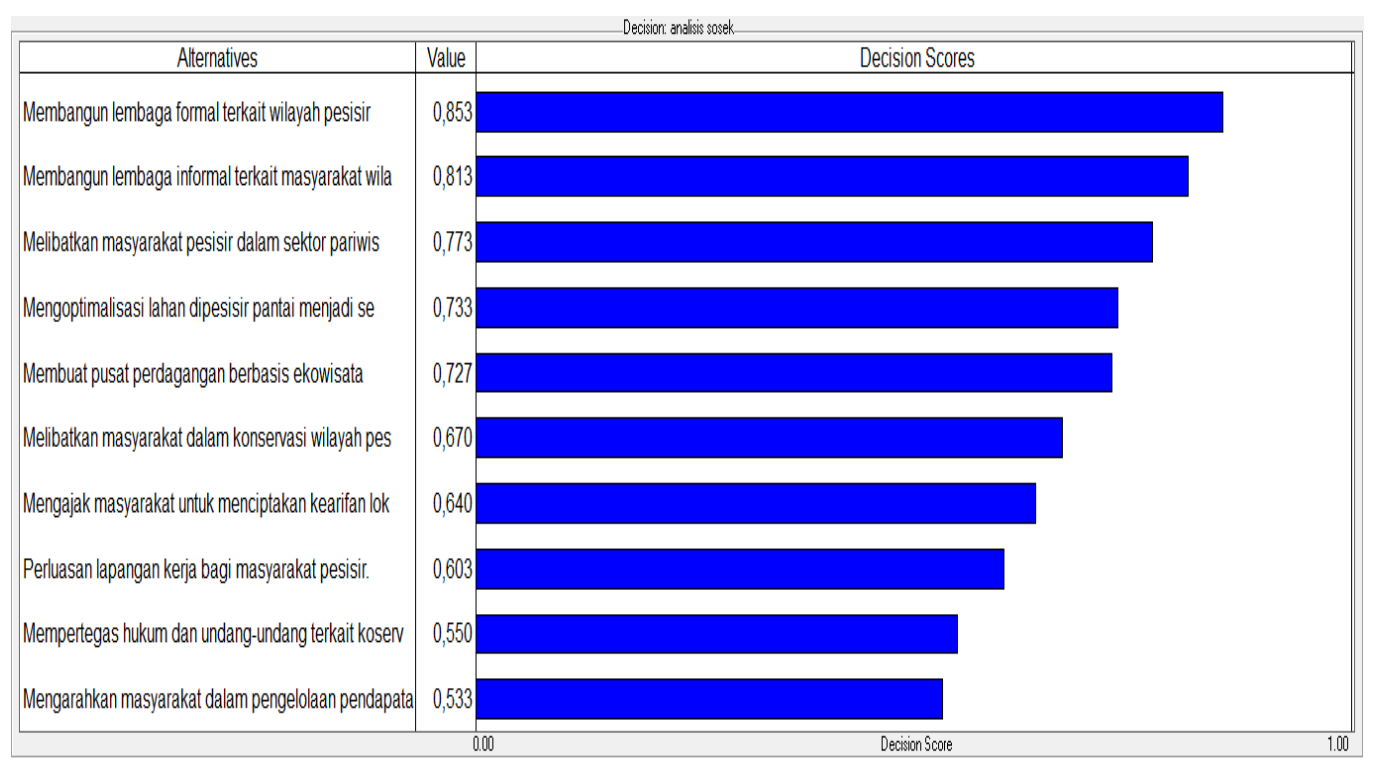

Figure 2. Priorities of Alternative Policies in the Development of the Socio-Economic Growth of Coastal Society in Belitung Regency

In Figure 2, the alternative policies are compiled into policy priorities based on the highest scores. Five policy priorities are obtained, namely: (1) involving the coastal society in the tourism sector with the score $(0.773)$, (2) making ecotourism based trade center with the score $(0.727)$, (3) optimizing the use of the land seashores into economy sectors with the score $(0.733)$, (4) establishing informal institutions related to coastal society with the score $(0,813)$, and (5) establishing the formal institutions related to coastal area with the score (0.853). Each of these policies will be done through the implementation of the following:

1. Involving the coastal society in the tourism sector (a) Giving the freedom to coastal society to manage the tourism sector, (b) Inviting the castal society to have discussions with the local government related to the development of tourism, (c) Issues which will be held in the coastal area (d) Increasing the coastal society participation in tourism development from the process of planning to the implementation, (d) Having the openness between the related local government agencies and the coastal society also the institution associated with the coastal society in order to create transparency and continuity in the development of tourism

2. Making ecotourism based trade center, (a) The coastal society forming the committee or agency for the management of ecotourism activities with the support from governments and society organizations, (b) Developing ecotourism infrastructure, the guides should be local people, (c) Starting, managing, and maintaining of the tourism spots are the responsibility of the local community, including the cost charge to the visitors, (d) Developing the scheme where the visitors are voluntarily involved in the conservation and management of ecotourism region during their visit

3. Optimizing the use of the land seashores into economy sectors (a) Involving the coastal society in the conservation of land on the seashores, (b) Using the existing resources optimally such as resort, trade, tourist transport services, etc., (c) Conserving and developing the local wisdom of coastal society, (d) The coastal society renting their lands to tourism operators to be developed as an object and a tourist attraction as well as participating in monitoring the impacts arising in connection with the development of tourism

4. Establishing informal institutions related to coastal society, (a) Making the economic empowerment of coastal society through groups economic development of coastal society activities, (b) Establishing the 
community group swakarsa as the safety of marine resources, (c) Creating the development program of marine area, (d) Increasing the education, training, research and development in coastal areas

5. Establishing the formal institutions related to coastal area, (a) Setting up the cooperatives to facilitate economies of coastal society, (b) Internalizing the program of marine protected areas into the annual program of the local government, so that the management of marine protected areas can always get help and guidance from the local government, (c) Building the advanced assisted program by other donor agencies to optimize the development of the coastal region tourism, (d) Setting up the NGO to build the local community and to keep the coastal areas in the tourism sector

\section{Conclusion}

Based on the research conducted, it can be concluded that the local government has attempted to improve the economy of Belitung Regency society by building the tourism sector since Belitung Regency has the potential to be developed for tourism. The plan has been running about $30 \%$ and is expected to be completed in 2018. With the construction of coastal areas into the tourism sector, it will bring a huge impact to the surrounding community, including providing great job opportunities for coastal society, and increasing the incomes of the coastal society approximately to 30 percent higher. Policy priorities were taken into consideration in the decision-making with respect to the analysis of the economic growth level of coastal society in Belitung Regency. The five alternatives policy priorities are: (1) involving the coastal society in the tourism sector, (2) making ecotourism based trade center, (3) optimizing the use of the land seashores into economy sectors, (4) establishing informal institutions related to coastal society, and (5) establishing the formal institutions related to coastal area.

\section{Reference}

A. K. Fitria. (2014). Analisis Potensi Lokal di Wilayah Pesisir Kabupaten Kendal Dalam Upaya Mewujudkan Blue Economy. Journal

Badan Pusat Statistik Kabupaten Bangka Belitung. (2015). Kabupaten Belitung Dalam Angka, BPS Kabupaten Belitung.

Effendy, M. (2009). Pengelolaan Wilayah Pesisir Secara Terpadu: Solusi Pemanfaatan Ruang, Pemanfaatan Sumberdaya dan Pemanfaatan Kapasiatas Asimilasi Wilayah Pesisir yang Optimal dan Berkelanjutan. Journal.

Harahap R H. (2015). Pengelolaan Wilayah Pesisir Berbasis Masyarakat Yang Berkelanjutan. Journal.

Hidayat, A. (2012). Analisis Pengembangan Kawasan Pesisir Berbasis Mitigasi Sea Level Rise (Kenaikan Muka Air Laut) Studi Kasus Kawasan Kota Lama Makassar. Journal.

Miraza Razak 2009, 'Implementasi Program Pemberdayaan Ekonomi Masyarakat $\quad$ Pesisir (PEMP) di Kecamatan Tanjung Pura Kabupaten Langkat. Journal.

Musiyam M. (2011). Model Pengembangan Kawasan Minapolitan Sebagai Upaya Dalam Meningkatkan Pertumbuhan Ekonomi Lokal Kabupaten Pacitan. Jurnal

Oktama R Z. (2013). Pengaruh Kondisi Sosial Ekonomi Terhadap Tingkat Pendidikan Anak Keluarga Nelayan di Kelurahan Sugihwaras Kecamatan Pemalang Kabupaten Pemalang. Journal.

Ristianto. (2011). Kerentanan Wilayah Pesisir Terhadap Kenaikan Muka Laut (Studi Kasus Wilayah Pesisir Utara Jawa Barat). Journal.

\section{Yudi Antomi}

Lecturers of Master Program of Geography Education

Faculty of Social Science, Universitas Negeri Padang, Indonesia

\section{Paus Iskarni}

Lecturers of Master Program of Geography Education

Faculty of Social Science, Universitas Negeri Padang, Indonesia 